\title{
EKSISTENSI SOLITON PADA PERSAMAAN KORTEWEG-DE VRIES
}

\author{
AULIA OKTAVIA, MAHDHIVAN SYAFWAN \\ Program Studi Matematika, \\ Fakultas Matematika dan Ilmu Pengetahuan Alam, Universitas Andalas, \\ Kampus UNAND Limau Manis Padang, Indonesia. \\ aulia.oktavia17@gmail.com
}

\begin{abstract}
Abstrak. Pada artkel ini dikaji penjelasan tentang eksistensi solusi soliton pada persamaan Korteweg-de Vries (KdV). Fokus pengkajian diutamakan pada penurunan solusi soliton, sifat-sifat persamaan KdV dengan memahami efek dispersi dan kenonlinierannya, dan interaksi dua soliton pada persamaan $\mathrm{KdV}$.
\end{abstract}

Kata Kunci: Soliton, persamaan Korteweg-de Vries

\section{Pendahuluan}

Soliton didefinisikan sebagai gelombang nonlinear terlokalisasi yang memenuhi sifat $[3,6]$ sebagai berikut.

(1) Dapat mempertahankan bentuknya saat merambat pada kecepatan konstan, dan

(2) dapat berinteraksi dengan soliton lain namun tetap mempertahankan identitasnya semula.

Kondisi pertama merefleksikan karakteristik dari gelombang soliter, sedangkan yang kedua menggambarkan sifat interaksi seperti partikel, yang darinya nama soliton diperkenalkan pertama kali pada tahun 1965 oleh Norman Zabusky dan Martin Kruskal [2].

Adapun yang dimaksud dengan gelombang yang terlokalisasi pada artikel ini adalah gelombang yang memiliki puncak dengan ekor yang menurun secara eksponensial menuju nol bilamana koordinat spasial $x$ menuju $\pm \infty$ (lihat Gambar 1). Salah satu persamaan yang memiliki solusi soliton adalah persamaan Korteweg-de Vries (KdV). Persamaan KdV adalah sebuah model matematika yang menggambarkan perambatan gelombang air pada lorong (chanel) yang tidak terlalu lebar [2]. Persamaan KdV menjadi salah satu persamaan penting yang mendasari teori soliton karena memiliki sifat-sifat matematika yang menarik. Studi tentang persamaan ini dapat digunakan untuk memahami ide-ide dasar dari konsep soliton.

Penulisan pada artikel ini disusun dengan sistematika sebagai berikut. Pada bagian II dijelaskan sejarah soliton dan persamaan Korteweg-de Vries. Kemudian pada bagian III diturunkan solusi soliton pada persamaan KdV. Selanjutnya, sifatsifat persamaan KdV yang dilihat dari efek dispersi dan kenonlinieran, serta inter- 


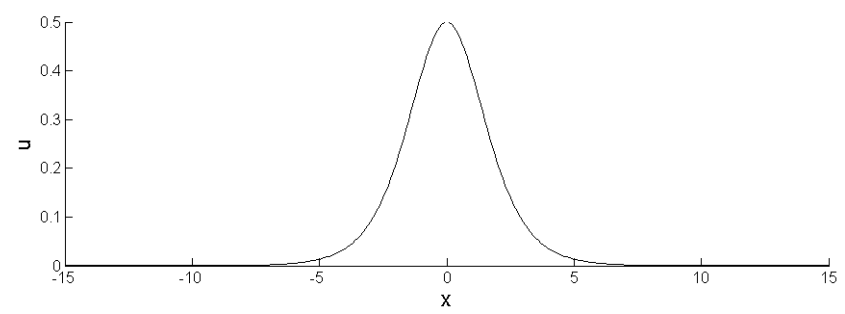

Gambar 1. Contoh gelombang yang terlokalisasi.

aksi dua soliton dibahas pada bagian IV dan V. Terakhir pada bagian VI disajikan kesimpulan dan usulan studi berikutnya.

\section{Sejarah Soliton dan Persamaan Korteweg-de Vries}

Fenomena soliton dilaporkan pertama kali oleh John Scott Russel pada tahun 1834 ketika dia mengendarai kudanya sepanjang kanal dekat Edinburgh, Skotlandia [7]. Ketika itu, dia sedang melakukan percobaan untuk mengukur hubungan antara kecepatan perahu yang ditarik kuda dan gaya dorongnya. Suatu ketika, perahu tersebut tiba-tiba berhenti karena tali penarik perahu putus. Menariknya, dia mengamati bahwa sejumlah massa air kanal di depan perahu membentuk suatu gelombang "tunggal" yang berjalan dengan kecepatan konstan. Dia kemudian mengikuti gelombang itu dan mengamati bahwa gelombang tersebut masih tetap berjalan dengan kecepatan konstan dan mempertahankan bentuk awalnya sejauh lebih dari dua mil.

Russel sangat antusias terhadap penemuan fenomena yang tidak disengaja ini. Untuk mereka ulang dan menganalisis lebih lanjut gelombang tersebut, dia kemudian melakukan beberapa percobaan pada sebuah tangki dengan desain khusus sepanjang 10 meter di belakang halaman rumahnya.

Hasil-hasil percobaan tersebut kemudian dilaporkannya pada pertemuan British Association for the Advancement of Science pada tahun 1844. Akan tetapi komunitas ilmuwan yang hadir pada pertemuan tersebut tidak memberikan respon positif dikarenakan temuan tersebut tidak dapat dijelaskan dengan teori gelombang yang dipahami pada masa itu.

Penjelasan teoritis tentang gelombang yang ditemukan oleh John Scott Russel baru dapat dikemukakan oleh Diederik Johannes Korteweg dan mahasiswa PhDnya, Gustav de Vries, pada tahun 1895. Mereka menurunkan suatu persamaan diferensial parsial nonlinier yang mengkonfirmasi eksistensi gelombang soliton yang John Scott Russel temukan. Persamaan ini kemudian dikenal dengan persamaan Korteweg-de Vries yang diberikan oleh [3] berikut,

$$
\frac{\partial \eta}{\partial t}=\frac{3}{2} \sqrt{\frac{g}{l}} \frac{\partial}{\partial x}\left(\frac{2}{3} \alpha \eta+\frac{1}{2} \eta^{2}+\frac{1}{3} \sigma \frac{\partial^{2} \eta}{\partial x^{2}}\right),
$$

dimana $l$ adalah kedalaman fluida, $\alpha$ adalah sebarang konstanta, $\sigma=l^{3} / 3-T l / \rho g$ ( $T$ adalah tegangan permukaan dan $\rho$ adalah massa jenis air) dan $\eta(x, t)$ adalah ketinggian permukaan di atas ekuilibriumnya. Proses pemodelan persamaan KdV di atas dapat dilihat pada [2]. 


\section{Solusi Soliton pada Persamaan Korteweg-de Vries}

Dengan menggunakan transformasi berikut :

$$
\eta(x, t)=\frac{2}{3} \alpha(6 \phi(\xi, \tau)-1), \quad \tau=-\sqrt{\frac{2 \alpha^{3} g}{\sigma l}} t, \quad \xi=\sqrt{\frac{2 \alpha}{\sigma}} x,
$$

persamaan (2.1) dapat disederhanakan menjadi

$$
\phi_{\tau}+6 \phi \phi_{\xi}+\phi_{\xi \xi \xi}=0 .
$$

Untuk menentukan solusi soliton berjalan dari persamaan KdV (3.1), gunakan substitusi $\phi(\xi, \tau)=f(z)$, dimana $z=\xi-v \tau$ dan $f(z), f^{\prime}(z), f^{\prime \prime}(z) \rightarrow 0$ bilamana $z \rightarrow \pm \infty$, sehingga diperoleh

$$
-v f^{\prime}+6 f f^{\prime}+f^{\prime \prime \prime}=0 .
$$

Persamaan (3.2) kemudian diintegralkan sekali sehingga diperoleh

$$
-v f+3 f^{2}+f^{\prime \prime}=a,
$$

dimana $a$ adalah konstanta integrasi. Nilai $f(z), f^{\prime \prime}(z) \rightarrow 0$ bilamana $z \rightarrow \pm \infty$, sehingga nilai $a=0$. Dengan mengalikan kedua ruas persamaan (3.3) dengan $f^{\prime}$ dan kemudian integralkan sekali lagi, diperoleh

$$
-\frac{1}{2} v f^{2}+f^{3}+\frac{1}{2}\left(f^{\prime}\right)^{2}=b
$$

dengan $b$ suatu konstanta integrasi. Karena nilai $f(z), f^{\prime}(z) \rightarrow 0$ bilamana $z \rightarrow \pm \infty$, maka nilai $b=0$. Akibatnya

$$
\left(f^{\prime}\right)^{2}=(v-2 f) f^{2}
$$

sehingga

$$
\frac{f^{\prime}}{\sqrt{v-2 f}}=1
$$

dengan syarat $v>2 f$. Misalkan $g^{2}=v-2 f$, maka $f=\frac{v-g^{2}}{2}$ dan $f^{\prime}=-g g^{\prime}$. Dengan demikian persamaan (3.6) menjadi

$$
\frac{2}{v-g^{2}} g^{\prime}=-1 \text {. }
$$

Dengan menggunakan integral parsial, integrasi kedua sisi persamaan (3.7) terhadap $z$ memberikan hasil

$$
\ln \left(\frac{\sqrt{v}+g}{\sqrt{v}-g}\right)=-\sqrt{v} z+d,
$$

dengan $d$ suatu konstanta. Akibatnya

$$
g(z)=\sqrt{v} \frac{\exp (-\sqrt{v} z+d)-1}{\exp (-\sqrt{v} z+d)+1}=-\sqrt{v} \tanh \left[\frac{1}{2}(\sqrt{v} z-d)\right],
$$

dan

$$
f(z)=\frac{v}{2} \operatorname{sech}^{2}\left[\frac{\sqrt{v}}{2}(z-d)\right]
$$


Karena $d$ merupakan geseran fasa gelombang, maka tanpa mengurangi keumuman dapat dipilih $d=0$. Dengan demikian solusi gelombang soliton berjalan dari persamaan $\mathrm{KdV}$ diberikan oleh

$$
\phi(\xi, \tau)=A \operatorname{sech}^{2}\left[\sqrt{\frac{A}{2}}(\xi-2 A \tau)\right],
$$

$\operatorname{dimana} A=\frac{v}{2}$.

\section{Sifat Persamaan Korteweg-de Vries}

Pada bagian ini akan dibahas sifat-sifat persamaan Korteweg-de Vries dengan memahami efek yang ditimbulkan oleh suku dispersif dan nonliniernya. Hal ini bertujuan untuk menjelaskan mengapa solusi soliton dapat terbentuk pada persamaan KdV. Penjelasan sifat-sifat persamaan KdV dalam bagian ini akan dibagi dalam beberapa kasus.

\subsection{Kasus Linier Nondispersif}

Pada kasus linier nondispersif, persamaan KdV dapat ditulis

$$
\phi_{\tau}+v \phi_{\xi}=0
$$

dimana $v$ suatu konstanta. Dengan menggunakan metode karakteristik, solusi persamaan (4.1) dengan syarat awal $\phi_{0}(\xi)$ diberikan oleh

$$
\phi(\xi, \tau)=\phi_{0}(\xi-v \tau)
$$

Jika dipilih syarat awal

$$
\phi_{0}(\xi)=A \operatorname{sech}^{2}\left[\sqrt{\frac{A}{2}} \xi\right],
$$

dengan $A=v / 2$, maka solusi dari persamaan (4.1) diberikan oleh persamaan (3.11). Visualisasi dari solusi tersebut untuk beberapa waktu $\tau$ dan $v=1$ diberikan oleh Gambar 2.

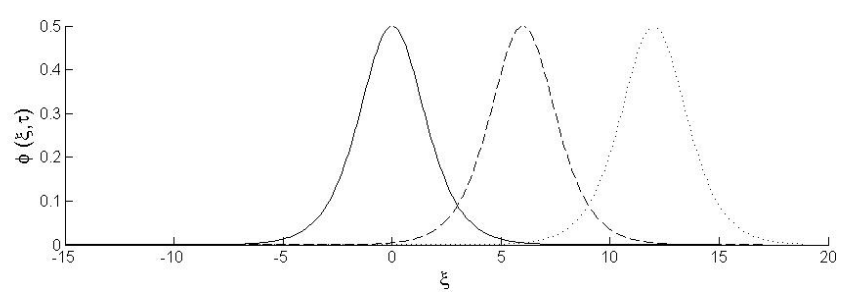

Gambar 2. Profil solusi persamaan KdV linier nondispersif dengan syarat awal (4.3) untuk $v=1$ pada waktu $\tau=0$ (garis utuh), $\tau=2$ (garis putus-putus), dan $\tau=4$ (garis titik-titik).

Dari Gambar 2 dapat dilihat bahwa gelombang linier nondispersif $\phi(\xi, \tau)$ berjalan dengan kecepatan konstan dan profil yang tidak berubah. 


\subsection{Kasus Nonlinier Nondispersif}

Persamaan KdV pada kasus nonlinier dan nondispersif diberikan oleh

$$
\phi_{\tau}+6 \phi \phi_{\xi}=0
$$

Misalkan untuk persamaan ini diberikan syarat awal

$$
\phi(\xi, 0)=\phi_{0}(\xi) .
$$

Kurva karakteristik yang dimulai dari titik $\left(\xi_{0}, 0\right)$ untuk persamaan (4.4) diberikan oleh

$$
\xi=6 \phi_{0}\left(\xi_{0}\right) \tau+\xi_{0}
$$

Jika dipilih syarat awal

$$
\phi_{0}(\xi)=A \operatorname{sech}^{2}\left[\sqrt{\frac{A}{2}} \xi\right],
$$

maka persamaan (4.6) menjadi

$$
\xi=6 A \operatorname{sech}^{2}\left[\sqrt{\frac{A}{2}} \xi_{0}\right] \tau+\xi_{0} .
$$

Dengan demikian solusi $\phi(\xi, \tau)$ diberikan oleh

$$
\phi(\xi, \tau)=A \operatorname{sech}^{2}\left[\sqrt{\frac{A}{2}} \xi_{0}\right],
$$

dimana $\xi=6 A \operatorname{sech}^{2}\left[\sqrt{\frac{A}{2}} \xi_{0}\right] \tau+\xi_{0}$. Nilai $\xi_{0}$ untuk setiap $\xi$ dapat dihitung secara numerik.

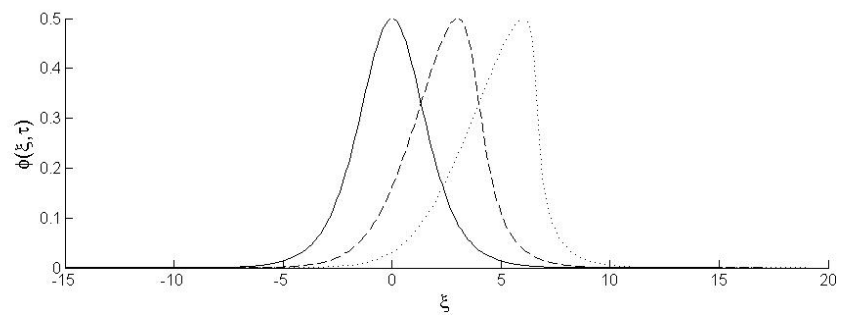

Gambar 3. Profil solusi persamaan $\mathrm{KdV}$ nonlinier nondispersif dengan syarat awal (4.7) untuk $A=v / 2$ pada waktu $\tau=0$ (garis utuh), $\tau=2$ (garis putus-putus), dan $\tau=4$ (garis titik-titik).

Dari kurva karakteristik (4.8) dapat disimpulkan bahwa gelombang nonlinier nondispersif $\phi(\xi, \tau)$ berjalan dengan kecepatan $6 \phi(\xi, \tau)$. Akibatnya bagian $\phi$ yang amplitudonyo lebih besar cenderung untuk bergerak lebih cepat dibandingkan dengan bagian yang amplitudonyo lebih kecil. Hal ini dikonfirmasi oleh Gambar 3. 
14 Aulia Oktavia, Mahdhivan Syafwan

\subsection{Kasus Linier Dispersif}

Pada kasus linier dan dispersif, persamaan KdV dapat ditulis

$$
\phi_{\tau}+\phi_{\xi \xi \xi}=0
$$

Transformasi Fourier (terhadap $\xi$ ) dari persamaan di atas adalah

$$
\widehat{\phi}_{\tau}=-i k^{3} \widehat{\phi}
$$

dimana $\widehat{\phi} \equiv \widehat{\phi}(k, \tau)$. Perlu dicatat disini bahwa transformasi Fourier dapat dikenakan pada persamaan (4.10) karena solusi $\phi$ yang dicari adalah solusi yang memiliki syarat batas $\phi(\xi, \tau) \rightarrow 0$ bilamana $\xi \rightarrow \pm \infty$. Solusi umum dari persamaan (4.11) adalah

$$
\widehat{\phi}=A(k) \exp \left(-i k^{3} \tau\right)
$$

Sekarang misalkan syarat awal untuk persamaan (4.10) adalah

$$
\phi(\xi, 0)=f(\xi)
$$

dimana $f(\xi) \rightarrow 0$ bilamana $\xi \rightarrow \pm \infty$. Jelas bahwa transformasi Fourier dari syarat awal di atas diberikan oleh

$$
\widehat{\phi}(k, 0)=\widehat{f}(k) .
$$

Dengan mensubstitusikan persamaan (4.14) ke solusi umum (4.12), diperoleh solusi khusus

$$
\widehat{\phi}=\widehat{f}(k) \exp \left(-i k^{3} \tau\right)
$$

Perhatikan bahwa

$$
\begin{aligned}
\mathcal{F}^{-1}\left(\exp \left(-i k^{3} \tau\right)\right) & =\frac{1}{2 \pi} \int_{-\infty}^{\infty} \exp (-i k \xi) \exp \left(-i k^{3} \tau\right) d k \\
& =\frac{1}{2 \pi} \int_{-\infty}^{\infty} \exp \left(i\left(-k \xi-k^{3} \tau\right)\right) d k
\end{aligned}
$$

Dari persamaan terakhir diperoleh relasi dispersi

$$
\omega(k)=-k^{3} .
$$

Dengan menggunakan Teorema Konvolusi, invers transformasi Fourier dari persamaan (4.15) adalah

$$
\begin{aligned}
\phi(\xi, \tau) & =f(\xi) * \frac{1}{2 \pi} \int_{-\infty}^{\infty} \exp \left(i\left(-k \xi-k^{3} \tau\right)\right) d k \\
& =\frac{1}{2 \pi} \int_{-\infty}^{\infty} f(\xi-p)\left(\int_{-\infty}^{\infty} \exp \left(i\left(-k p-k^{3} \tau\right)\right) d k\right) d p
\end{aligned}
$$

Hasil integrasi pada persamaan di atas dapat dihitung secara numerik. Visualisasi solusi $\phi(\xi, \tau)$ dengan syarat awal $f(\xi)=A \operatorname{sech}^{2}\left[\sqrt{\frac{A}{2}} \xi\right]$ untuk $A=4$ diberikan oleh Gambar 4.

Dari Gambar 4 dapat dilihat bahwa efek dari dispersi membuat gelombang tersebut menyebar. Hal ini disebabkan karena relasi dispersi dari persamaan (4.16) 


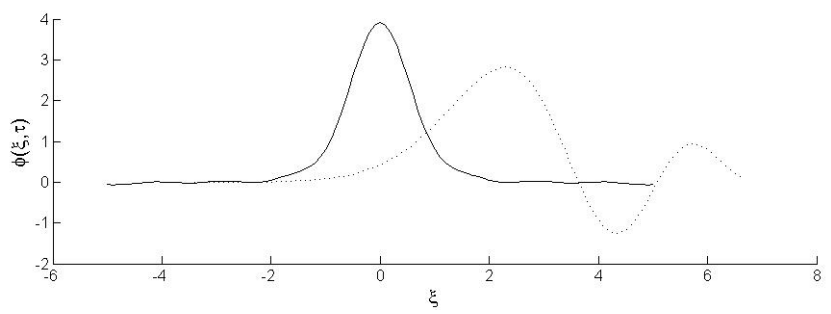

Gambar 4. Profil solusi persamaan linier dispersif untuk $A=4$ pada saat $\tau=0$ (garis utuh), $\tau=0.5$ (garis putus-putus)

adalah nonlinier, sehingga komponen Fourier dari gelombang merambat dengan kecepatan yang berbeda (yaitu $\left.c(k)=\frac{\omega(k)}{k}=-k^{2}\right)$.

Dari penjelasan sifat-sifat persamaan KdV di atas dapat disimpulkan bahwa efek nonlinier cenderung untuk melokalisasi gelombang sedangkan dispersi cenderung membuat gelombang menyebar. Oleh karena itu, ketika kedua efek ini berlaku pada persamaan KdV, maka akan ada situasi dimana terjadi keseimbangan antara efek nonlinier dan dispersi. Jika nilai awal terlalu sempit, maka efek dispersi mendominasi sehingga gelombang cenderung untuk menyebar sampai mencapai keseimbangan. Sebaliknya, jika nilai awal terlalu lebar, maka efek dispersi didominasi oleh efek nonlinier yang cenderung untuk melokalisasi gelombang sampai mencapai keseimbang-an. Pada situasi seimbang inilah kemudian soliton dapat terbentuk.

\section{Interaksi Dua Soliton}

Selain solusi satu soliton, persamaan KdV juga memiliki solusi beberapa soliton yang disebut multi-soliton. Untuk solusi dua soliton, diberikan oleh [6]

$$
\phi(\xi, \tau)=12 \frac{3+4 \cosh (2 \xi-8 \tau)+\cosh (4 \xi-64 \tau)}{[3 \cosh (\xi-28 \tau)+\cosh (3 \xi-36 \tau)]^{2}} .
$$

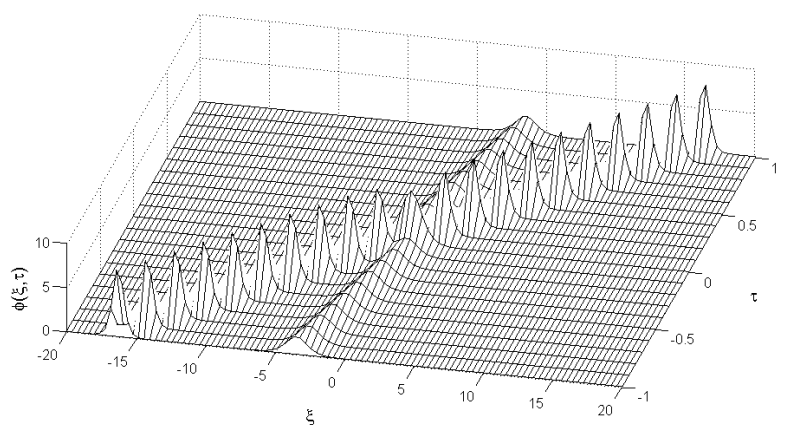

Gambar 5. Profil solusi dua-solition pada persamaan KdV yang diberikan oleh persamaan (5.1) 
Dari Gambar 5 dapat dilihat bahwa pada solusi 2-soliton, soliton dengan amplitudo yang lebih besar bergerak lebih cepat dibandingkan dengan soliton dengan amplitudo yang lebih kecil. Masing-masing soliton bergerak dengan kecepatan konstan. Kedua soliton ini kemudian bertubrukan (berinteraksi). Setelah berinteraksi, kedua soliton ini tetap mempertahankan bentuk dan kecepatanya semula.

\section{Kesimpulan}

Berdasarkan uraian sebelumnya, dapat diberikan kesimpulan sebagai berikut :

(1) Solusi soliton pada persamaan KdV berbentuk secant hiperbolik yang merambat dengan kecepatan konstan dan dengan profil yang tidak berubah.

(2) Efek nonlinier pada persamaan KdV cenderung untuk melokalisasi gelombang, sedangkan efek dispersif cenderung membuat gelombang menyebar.

(3) Berdasarkan observasi, dapat disimpulkan bahwa eksistensi dari solusi soliton pada persamaan KdV terjadi karena keseimbangan antara dua efek, yaitu nonlinier dan dispersi.

(4) Ketika suatu soliton berinteraksi dengan soliton lainnya, profil dan kecepatan kedua soliton tersebut tidak berubah setelah berinteraksi.

Untuk penelitian selanjutnya, penulis menyarankan untuk mengkaji penyelesaian matematis dari solusi multisoliton pada persamaan KdV. Di samping itu, studi tentang soliton pada bidang aplikasi lainnya, seperti biofisika (DNA), teknologi informasi, dan sebagainya juga akan menarik untuk dikaji.

\section{Ucapan Terima Kasih}

Penulis mengucapkan terima kasih kepada Bapak Muhafzan, Bapak Narwen dan Ibu Susila Bahri yang telah memberikan masukan dan saran dalam penyempurnaan penulisan artikel ini.

\section{Daftar Pustaka}

[1] Boyce, W. E dan Diprima, R. C. 2001. Elementary Differential Equations and Boundary Value Problems. $7^{\text {th }}$ Ed. John Wiley and Sons : New York

[2] Dauxois, T dan Michel, P. 2010. Physics of Solitons. Cambridge University Press: Cambridge

[3] Drazin, P. G. dan Johnson, R. S. 1989. Solitons : An Introduction. Cambridge University Press. Cambridge

[4] Knobel, R. 2000. An Introduction to the Mathematical Theory of Waves. United States of America

[5] Kreyszig, E. 2011. Advanced Engineering Mathematics. $10^{\text {th }}$ Ed. Wiley and Sons: New York

[6] Scott, A. 2005. Encyclopedia of Nonlinear Science. Taylor and Francis Group : New York

[7] Scott Russel, J. 1844. Report on Waves, Rep. Meet. British Assoc. Adv. Sci 14: 311 